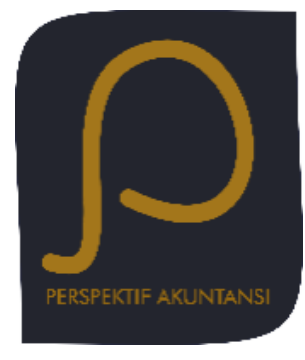

Perspektif Akuntansi

Volume 2 Nomor 2 (Juni 2019), hal. 121-141

ISSN: 2623-0194 (Print), 2623-0186 (Online) Copyright@ The Authors(s). All Rights Reserved

Fakultas Ekonomika dan Bisnis,

Universitas Kristen Satya Wacana

DOI: https://doi.org/10.24246/persi.v1i2.p121-144

http://ejournal.uksw.edu/persi

\title{
Local Wisdom: Deskripsi, Tantangan, dan Peluangnya dalam Penelitian Interpretif
}

\author{
Supatmi ${ }^{1}$ \\ Fakultas Ekonomika dan Bisnis, Universitas Kristen Satya Wacana
}

Received

07 Januari 2019

Abstract. This paper aims to describe the use of local wisdom concepts in accounting and business research and finds the challenges and opportunities of using local wisdom concepts for

Accepted

20 Juni 2019 intepretive researchers in Indonesia for international publication purposes. By using 60 articles published in national and international journals, the description results that local wisdom is widely used in the management accounting studies, with the type/form of local or tribal culture, and many use ethnographies as a research method. Learning from 12 articles published in reputable international journals, challenges and opportunities in using local wisdom concepts in order to deserve publication in international journals, researchers must concern about research methods and types/forms of local wisdom.

Keywords: Local wisdom, interpretive paradigm, challenges, opportunities

Abstrak. Tulisan ini bertujuan untuk mendeskripsikan
penggunaan konsep kearifan lokal dalam penelitian akuntansi dan
bisnis, serta menemukan tantangan dan peluang penggunaan
konsep kearifan lokal bagi peneliti intepretif di Indonesia dalam
rangka publikasi internasional. Dengan menggunakan 60 artikel
bermuatan kearifan lokal yang dipublikasikan di jurnal nasional
maupun internasional, hasil deskripsi menunjukkan kearifan lokal
banyak digunakan dalam bidang kajian ilmu akuntansi
manajemen, dengan jenis/bentuk kearifan lokal budaya daerah
atau suku, dan banyak menggunakan etnografi sebagai metode
penelitian. Belajar dari 12 artikel yang diterbitkan dalam jurnal

${ }^{1}$ patmie@staff.uksw.edu 
internasional bereputasi, tantangan dan peluang untuk penggunaan konsep kearifan lokal agar layak dipublikasikan di jurnal internasional, para peneliti harus memperhatikan metode penelitian dan jenis/bentuk kearifan lokal.

Kata kunci: Kearifan lokal, paradigma interpretif, tantangan, peluang

\section{Pendahuluan}

Perkembangan penelitian di bidang akuntansi selama satu dekade terakhir tidak lagi bersifat monodisipliner, melainkan multidisipliner. Akuntansi yang selama ini banyak dikenal dengan sub bidang kajian akuntansi keuangan, akuntansi manajemen, auditing, perpajakan, dan akuntansi sektor publik, mulai berkolaborasi dengan bidang ilmu lainnya. Psikologi dan sosiologi merupakan dua bidang ilmu lain yang sangat mempengaruhi perkembangan penelitian di bidang akuntansi.

Theory of planned behavior (TPB) atau teori perilaku terencana yang diusulkan oleh Azjen (1991) merupakan teori dalam bidang ilmu psikologi yang sebelumnya banyak digunakan untuk mempelajari hubungan antara kepercayaan, sikap, kontrol perilaku terhadap perilaku di bidang periklanan, hubungan masyarakat, dan perawatan kesehatan. Namun, beberapa tahun ini TPB juga diadopsi dalam penelitian di bidang akuntansi. Penelitian akuntansi tentang pendeteksian perilaku wajib pajak dalam memenuhi kewajibannya, banyak menggunakan TPB sebagai teori penjelas. Begitu juga dalam auditing, TPB digunakan untuk menjelaskan faktor yang mempengaruhi tingkat penerimaan auditor atas software audit.

Sementara itu, pengaruh bidang ilmu sosiologi dalam penelitian akuntansi, lebih banyak lagi. Tulisan Burrel \& Morgan (1979) melalui bukunya yang berjudul Sociological Paradigms and Organisational Analysis, banyak dijadikan sebagai tonggak munculnya asumsi yang mendasari munculnya paradigma dalam penelitian. Melalui dua asumsi, yaitu sifat sains (the nature of social science), yaitu objektif atau subjektif, dan sifat masyaratkat (the nature of society), yaitu masyarakat yang teratur/teregulasi atau masyarakat yang berubah secara radikal.

Penelitian ilmiah akuntansi selama ini dikenal sebagai penelitian mainstream, yaitu mengedepankan objektifitas dan mengasumsikan bahwa masyarakat yang teratur/teregulasi. Namun, pemikiran Burrel \& Morgan (1979) memberikan pendekatan yang lain yang tidak memenuhi objektifitas dan atau asumsi keteraturan masyarakat. Oleh karena itu, penelitian ilmiah dapat dikelompokkan ke dalam empat paradigma, yaitu functionalist (mainstream), interpretive, radical humanist dan radical structuralist. Pendekatan non- 
mainstream ini tidak hanya memunculkan metode penelitian yang berbeda namun juga memunculkan ide-ide penelitian yang mengkolaborasikan ilmu akuntansi dengan ilmu sosiologi.

Salah satu bidang ilmu sosiologi yang banyak dilirik dan dibahas dalam berbagai bidang beberapa tahun belakangan ini adalah konsep kearifan lokal (local wisdom). Konsep kearifan lokal dalam penelitian akuntansi digunakan dalam berbagai paradigma penelitian, mulai dari positivis, interpretif, kritis, maupun postmodern. Akan tetapi, paradigma interpretiflah yang paling banyak menggunakan dan menggali konsep ini karena sesuai tujuan paradigma ini adalah untuk memahami dan menjelaskan tindakan-tindakan manusia (Neuman, 2014), termasuk tentang makna dan penggunaan kearifan lokal bagi masyarakat. Oleh karena itu, dapat kita temui dalam jurnal ilmiah berskala nasional maupun internasional berbagai macam kearifan lokal digunakan untuk menemukan makna tersembunyi dari suatu aktivitas bisnis atau bagian akuntansi yang belum terungkapkan.

Beberapa tahun terakhir terdapat berbagai macam kearifan lokal negara lain yang dipublikasikan melalui jurnal internasional (lihat lampiran), sebut saja budaya suku Maori di Selandia Baru (Craig et al., 2012), budaya wanita Jepang (Komori, 2012) kekhasan etnis Cina (Ezzamel \& Xiao, 2015), ataupun kekuatan hukum Islam di negara-negara Timur Tengah (Kamla, 2012). Sebagian diantaranya banyak terpublikasi di jurnal internasional yang bereputasi yang termasuk rangking 30 jurnal terbaik dalam bidang akuntansi dan bisnis menurut www.scimagojr.com.

Indonesia yang memiliki beragam suku, budaya, dan bahasa, tentu saja kaya akan berbagai macam kearifan lokal juga. Hal ini menarik untuk dikaji lebih dalam karena melalui penelitian intepretif akan dapat ditemukan makna tersembunyi dari suatu aktivitas bisnis atau bagian akuntansi yang belum terungkapkan. Temuan ini pastinya akan memperkaya perkembangan ilmu akuntansi, khususnya ilmu akuntansi yang berbasis lokal yang bisa jadi unik dan berbeda dengan ilmu akuntansi yang selama ini kita pahami. Bahkan, tidak menutup kemungkinan akan memunculkan teori-teori akuntansi baru.

Jika dicermati, belum banyak penelitian ilmiah di bidang akuntansi dan bisnis yang menggunakan konsep kearifan lokal di Indonesia yang dipublikasikan di jurnal berskala internasional, khususnya yang bereputasi. Cukup banyak ditemukan penggunaan konsep kearifan lokal di Indonesia dalam penelitian akuntansi dan bisnis yang dipublikasikan di jurnal berskala nasional dan sebagian besar hasil penelitian banyak yang berhenti di rak perpustakaan sebagai bagian untuk memenuhi syarat kelulusan belaka. Banyak diantara 
tulisan merupakan buah pemikiran bermutu dan mengandung nilai-nilai kearifan lokal yang berharga untuk dibagikan.

Dengan menggunakan 60 artikel yang menggunakan konsep kearifan lokal, tulisan ini bertujuan untuk mendeskripsikan berbagai macam kearifan lokal dan penggunaannya dalam penelitian di bidang akuntansi dan bisnis dengan pendekatan paradigma interpretif. Hasil deskripsi ini akan digunakan untuk menemukan adanya tantangan penggunaan konsep kearifan lokal yang belum digali, serta peluang bagi peneliti intepretif, khususnya di Indonesia, yang ingin menggunakan konsep kearifan lokal dalam rangka publikasi internasional. Hal ini diharapkan mampu mendorong peneliti intepretif untuk meningkatkan kualitas tulisan ilmiah yang menggunakan konsep kearifan lokal di Indonesia sehingga berani dan layak untuk diterbitkan di jurnal ilmiah berskala internasional yang bereputasi.

Untuk menjelaskan dan menjawab persoalan di atas, tulisan ini menggunakan artikel yang bermuatan kearifan lokal yang dikumpulkan dalam mata kuliah Riset Akuntansi Interpretif yang diselenggarakan oleh salah satu program doktor ilmu akuntansi di perguruan tinggi negeri di Jawa Timur. Terdapat 21 orang mahasiswa yang mengikuti mata kuliah tersebut dan setiap mahasiswa mengumpulkan tiga artikel sehingga total ada 63 artikel. Namun ketika dibaca lebih lanjut, terdapat tiga artikel yang tidak bermuatan kearifan lokal sehingga artikel yang dikaji lebih lanjut untuk menjawab problematika di sini adalah 60 artikel (lihat lampiran).

Dengan menggunakan 60 artikel, baik yang diterbitkan jurnal berskala nasional maupun internasional, akan dipetakan dan dideskripsikan sejauh mana konsep kearifan lokal digunakan dalam penelitian tersebut. Pemetaan atau deskripsi atas artikel akan dilihat dari aspek skala jurnal, bidang ilmu kajian, jenis atau bentuk kearifan lokal, dan metode penelitian yang digunakan. Selanjutnya, dengan menggunakan 12 artikel yang diterbitkan oleh jurnal internasional bereputasi dari 60 artikel tersebut, akan dibahas lebih lanjut untuk menemukan tantangan dan peluang penelitian interpretif yang mengangkat konsep kearifan lokal agar lebih layak untuk dipublikasikan di jurnal internasional bereputasi.

Untuk memudahkan pemahaman, pada bagian berikutnya akan didiskusikan tentang paradigma interpretif dan kearifan lokal, baik tentang definisi maupun karakteristiknya. Bagian selanjutnya tentang hasil dan pembahasahan hasil pemetaan 60 artikel tersebut dan dilanjutkan dengan mengindentifikasi tantangan dan peluangnya, serta bagian penutup berupa simpulan. 


\section{Telaah Pustaka}

\section{Paradigma Interpretif}

Menurut Neuman (2014) pendekatan interpretif merupakan salah satu pendekatan penelitian sosial yang menekankan pada makna aksi sosial, bagaimana makna dibentuk secara sosial, dan nilai relativisme. Tujuan utama paradigma ini untuk memahami dan menjelaskan tindakan-tindakan manusia. Menurut Burrel \& Morgan (1979) paradigma interpretif merupakan produk dari pemikiran sosial dan tradisi yang idealis dari Jerman. Melalui kwadran yang dibentuk, Burrel \& Morgan (1979:22) meletakkan paradigma interpretif berada pada pertemuan pendekatan subjektif dan asumsi masyarakat yang teratur/teregulasi sebagaimana dalam Gambar 1.

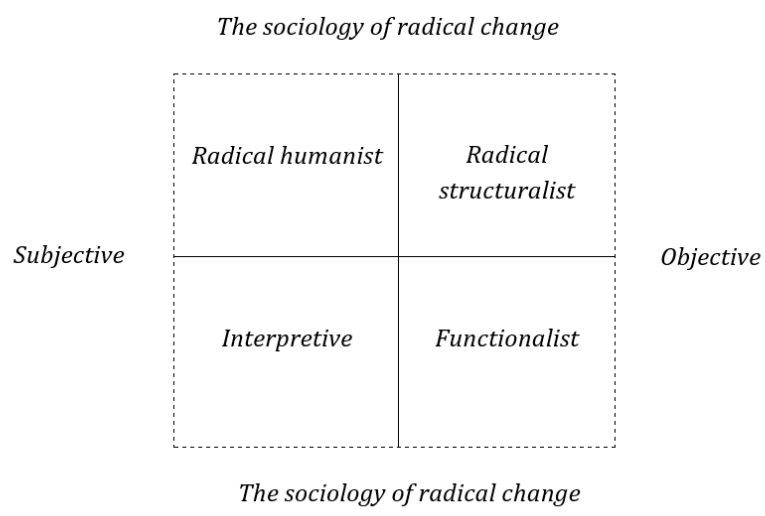

Gambar 1. Empat Paradigma untuk Analisis Teori Sosial Sumber: Burrel \& Morgan (1979)

Oleh karena masyarakat sudah teratur/teregulasi, maka pencarian kebenaran seharusnya lebih mendalam dengan terlibat langsung dengan obyek penelitian supaya peneliti mampu mengungkap sistem dengan interpretasi dan pemahaman (makna) yang ada dalam lingkungan sosial (Kamayanti, 2016). Sementara itu, menurut Chua (1986) paradigma interpretive perspective memiliki keyakinan bahwa penjelasan ilmiah dilakukan untuk tujuan manusia melalui interpretasi, subjektifitas, dan kesepakatan-kesepakatan yang bisa diketahui dengan studi kasus ataupun berpartisipasi langsung. Oleh karena itu, paradigma ini memandang teori dicari hanya untuk menjelaskan tindakan dan untuk memahami bagaimana masyarakat yang teratur dibentuk dan direproduksi.

Menurut Chua (1986) pendekatan ini memiliki konsekuensi atau hal-hal yang harus dipertimbangkan ketika menggunakan empat paradigma berikut: 
a) Pendekatan interpretif dalam praktik bisa memberikan makna atas informasi akuntansi yang berbeda namun makna ini juga didasari oleh perubahan dalam konteks politik, sosial, dan historis.

b) Makna akuntansi tidak hanya didasari oleh struktur dan proses interpretif yang komplek, tetapi juga didasari oleh realitas sosial yang obyektif.

c) Perspektif interpretif mempertanyakan pandangan akuntansi tradisional sebagai cara untuk mencapai tujuan yang telah ditetapkan.

d) Perspektif interpretif tidak mengasumsikan bahwa konflik adalah disfungsional.

Paradigma tersebut memiliki pendekatan untuk ilmu sosial yang termasuk nominalist, antipositivism, voluntarist, dan ideograhic. Hal ini berarti bahwa paradigma interpretif mengasumsikan bahwa manusia sebagai makhluk bebas (free-willed), dari sisi metodologi dengan terlibat langsung dengan subyek yang diteliti (ideographic), dari sisi ontology memandang realita hanya sekedar nama alias tidak nyata (nominalisme), dan dari sisi epistemology berpendapat bahwa dunia sosial hanya dapat dipahami dari sudut pandang individu yang secara langsung terlibat dalam aktifitas yang diteliti (Chariri, 2009).

Berdasarkan pada teori interpretif, tingkat subjektivitas ketika menginterpretasikan, Burrel \& Morgan (1979) mengidentifikan ada empat metode/pendekatan yang temasuk dalam paradigma ini antara lain solipsism, phenomenology, hermeneutics, dan phenomeno-logical sociology. Pendekatan hermeneutics merupakan metode yang paling rendah tingkat subjektivitasnya dibandingkan yang lain, sedangkan pendekatan solipsism yang paling tinggi tingkat subjektivitasnya. Selain itu, Neuman (2014) juga menyebutkan ada beberapa pendekatan dalam paradigma ini yang beberapa diantaranya sama halnya dengan pendekatan dalam Burrel \& Morgan (1979), yaitu hermeneutics, constructionism, ethnomethodology, cognitive, idealist, phenomenological, subjectivist, dan qualitative sociology.

\section{Kearifan Lokal (Local Wisdom)}

Kearifan lokal atau local wisdom terdiri dari kata local yang dapat diterjemahkan tempat, dan wisdom yang berarti bijaksana. Oleh karenanya, secara sederhana local wisdom dapat diartikan kearifan atau kebijaksanaan yang diyakini dan diikuti oleh anggota masyarakat setempat. Kearifan lokal di Indonesia menurut Meliono (2011) merupakan bentuk ekspresi dari sukusuku yang ada di Indonesia, ketika orang-orang melakukan kegiatan dan berperilaku sesuai dengan gagasan yang akhirnya menghasilkan karya-karya tertentu. Candi Borobudur, Candi Prambanan, maupun batik menunjukkan adanya ide-ide dan kegiatan yang mendasari dalam pembuatan artefak dan bentuk-bentuk produk etnis lainnya yang elegan dan megah di Indonesia 
(Meliono, 2011). Lebih lanjut dinyatakan bahwa kearifan lokal di Indonesia adalah kompilasi dari budaya suku-suku dan sebuah proses yang mengekspresikan kehidupan masyarakatnya melalui praktek-praktek pembelajaran.

Bentuk-bentuk kearifan lokal dalam masyarakat dapat berupa nilai, norma, etika, kepercayaan, adat-istiadat, hukum adat, dan aturan-aturan khusus. Oleh karena itu, kearifan lokal memiliki beberapa fungsi dalam masyarakat. Tama (2012) sebagaimana dikutip Wijayanto (2012) menyebutkan diantaranya untuk konservasi dan pelestarian sumber daya alam, pengembangan sumber daya manusia, pengembangan kebudayaan dan ilmu pengetahuan. Sementara itu, Samudra (2010) menyebutkan fungsi kearifan adalah sebagai petuah, kepercayaan, sastra dan pantangan, bermakna sosial, bermakna etika dan moral, bermakna politik, serta bermakna otonom karena memiliki nilai sakral untuk mendorong daerah menuju masyarakat yang otonom (Wijayanto, 2012). Nilai-nilai utama dalam bidang bisnis menurut Wijayanto (2012) merupakan hasil dari sosialisasi nilai-nilai filosofis yang terkandung dalam kearifan lokal.

\section{Hasil dan Pembahasan}

\section{Deskripsi}

Artikel-artikel yang digunakan untuk pendeskripsian dalam penelitian yang dibahas dalam tulisan ini menggunakan kearifan lokal sebagai ide utama penelitian. Secara umum penelitian dalam artikel-artikel tersebut dimotivasi oleh keinginan para peneliti untuk memahami dan menjelaskan tindakantindakan individu atau masyarakat dalam suatu aktivitas yang dikaitkan dengan nilai, norma, etika, kepercayaan, adat-istiadat, hukum adat, atau aturanaturan khusus yang diyakininya.

Hal tersebut sesuai dengan tujuan penelitian interpretif yaitu untuk memahami dan menjelaskan tindakan-tindakan manusia dengan menekankan pada makna aksi sosial, bagaimana makna dibentuk secara sosial, dan nilai relativisme (Neuman, 2014). Dengan berbagai metode penelitian, masing-masing peneliti mencoba menggali makna atas suatu tindakan individu atau masyarakat yang dilandasi oleh kearifan lokal yang diyakininya. Setelah proses baca dan identifikasi, hasil pemetaan berdasarkan skala jurnal, bidang kajian ilmu, jenis/bentuk local wisdom, serta metode penelitian yang digunakan setiap artikel dapat dirangkum dalam Tabel 1 berikut ini. 
Tabel 1. Tabulasi Silang Deskripsi Artikel

\begin{tabular}{lcc}
\hline \multicolumn{1}{c}{ Kategori } & Jumlah & Persentase \\
\hline Skala jurnal & & \\
Internasional & 38 & 63,33 \\
Nasional & 22 & 36,67 \\
\hline Bidang ilmu kajian & & \\
Akuntansi umum & 9 & 15 \\
Akuntansi keuangan & 12 & 20 \\
Akuntansi manajemen & 16 & 26,67 \\
Auditing & 3 & 5 \\
Sektor publik & 5 & 8,33 \\
Akuntabilitas & 7 & 11,67 \\
Lainnya & 8 & 13,33 \\
\hline Jenis/bentuk local wisdom & & \\
Religi & 5 & 8,33 \\
Budaya suku (daerah) & 29 & 48,33 \\
Budaya Negara & 21 & 35 \\
Etnis & 4 & 6,67 \\
Ajaran & 1 & 1,67 \\
\hline Metode penelitian & & \\
Etnografi & 7 & 11,67 \\
Etnometodologi & 3 & 5 \\
Arkeologi & 3 & 5 \\
Fenomenologi & 3 & 10 \\
Literatur & 6,67 \\
Studi kasus & 4 & 6,67 \\
Lainnya & 4,33 \\
Tidak disebutkan secara eksplisit & 4 & 46,67 \\
\hline Suber Data dion, 2017 & 5 &
\end{tabular}

Sumber: Data diolah, 2017

\section{Skala jurnal}

Berdasarkan skala jurnal, terlihat bahwa artikel yang dikumpulkan lebih banyak artikel berskala internasional dibandingkan nasional. Dari 38 artikel berskala internasional tersebut, 12 artikel diantaranya diterbitkan di jurnal internasional yang dikenal bereputasi bagus, yaitu Accounting, Auditing, \& Accountability (empat artikel); Accounting, Organization, and Society (empat artikel); Critical Perspectives on Accounting (tiga artikel), dan Journal of Bussiness Ethics (satu artikel). Terminologi jurnal internasional bereputasi di sini menurut Pendidikan Tinggi (Dikti) adalah jurnal yang sudah mendapat pengakuan para ilmuwan sedunia untuk mempublikasikan berbagai buah pemikiran atau hasil penelitian dari para ilmuwan, akademisi, dan praktisi dari berbagai disiplin ilmu (www.kopertis12.or.id). 
Sejauh ini Dikti mendasarkan reputasi jurnal tersebut sebagai jurnal yang terindeks Scopus atau publisher lainnya yang sudah ditentukan oleh Dikti. Keempat jurnal internasional di atas merupakan jurnal yang tidak hanya terindeks scopus, tetapi juga masuk dalam rangking 30 jurnal terbaik dalam bidang akuntansi dan bisnis menurut www.scimagojr.com, maka bisa dikatakan keempat jurnal tersebut sebagai jurnal dengan reputasi bagus pada periode 2016.

Penemuan 12 artikel tersebut menunjukkan bahwa penggunaan konsep kearifan lokal dalam penelitian kualitatif juga memiliki tempat di jurnal-jurnal internasional bereputasi tinggi. Hal ini mematahkan pendapat bahwa jurnaljurnal bereputasi hanya berada dalam paradigma positivism, karena terdapat jurnal-jurnal bereputasi tinggi yang mewadahi penelitian-penelitian kualitatif dengan topik spesifik. Selanjutnya, artikel internasional lainnya banyak diterbitkan melalui Procedia-Social and Behavioral Sciences (enam artikel) dengan publisher Science direct, dengan lima artikel diantaranya adalah hasil karya peneliti Indonesia.

\section{Bidang ilmu kajian}

Dari enam kategori bidang ilmu kajian, ditemukan konsep kearifan lokal banyak digunakan dalam pembahasan dalam bidang akuntansi manajemen dan keuangan. Tema yang dikaji dalam akuntansi manajemen beberapa diantaranya tentang Corporate Social Responsibility, sistem pengendalian manajemen, penggangaran, penentuan biaya, maupun proses produksi. Ini menunjukkan bahwa kajian tentang kearifan lokal terkait erat dengan aspek manajerial dan perilaku manajemen. Sedangkan tema yang dikaji dalam akuntansi keuangan terkait kearifan lokal dikaitkan dengan penilaian aset, penilaian kinerja keuangan, manajemen laba, maupun praktik akuntansi keuangan khusus. Bidang ilmu kajian berikutnya yang banyak dikaitkan dengan konsep kearifan lokal adalah akuntansi umum, akuntabilitas dan sektor publik. Sementara itu, delapan artikel yang berkategori lainnya terdiri dari bidang ilmu kajian tentang etika, entrepreneurship, bisnis, perpajakan, edukasi, dan keperilakuan. Deskripsi bidang ilmu kajian menunjukkan bahwa konsep kearifan lokal dapat diterapkan untuk dibahas dalam kajian apapun di bidang akuntansi dan bisnis.

\section{Jenis/bentuk local wisdom}

Terkait dengan jenis atau bentuk kearifan lokal yang didiskusikan dalam artikel-artikel yang dikaji, tema budaya daerah atau suku yang paling banyak digunakan, disusul budaya pada tingkat negara. Jika dicermati, sebagian besar pemilihan jenis atau bentuk kearifan lokal yang didiskusikan dalam artikel 
tersebut memiliki keterkaitan erat dengan peneliti, yaitu peneliti berasal atau merupakan bagian dari kearifan lokal tersebut. Sebagai contoh, Kamla (2012) mengangkat tema budaya wanita di Siria karena peneliti juga berdarah Siria meskipun sudah lama tinggal di negara lain. Kemudian Komori (2012) yang berketurunan Jepang dengan mengulas praktik akuntansi para ibu rumah tangga di Jepang. Hal ini menunjukkan bahwa keterikatan peneliti dengan kearifan lokal ikut mempengaruhi jenis atau bentuk kearifan lokal yang diteliti.
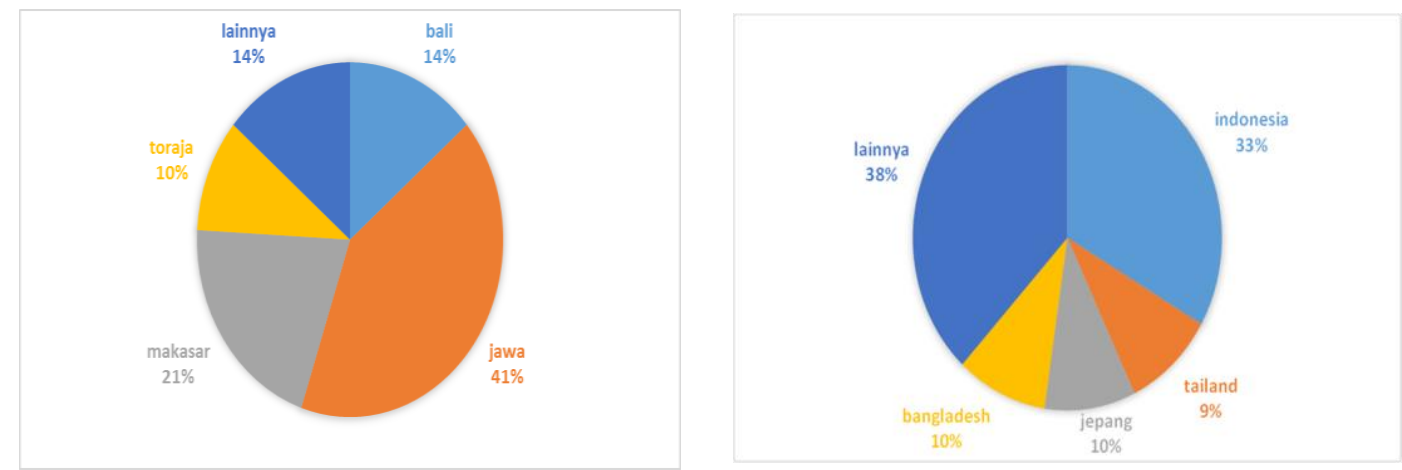

Diagram 1. Konsep Kearifan Lokal Menurut Jenis Budaya Daerah (Suku) dan Budaya Negara

Menurut Diagram 1 di atas nampak bahwa budaya Jawa, Makasar, dan Bali secara berurutan merupakan budaya daerah yang paling banyak diangkat dalam penelitian di Indonesia. Slametan, weton, memayu hayuning bawono, dan kerajaan Majapahit adalah beberapa budaya Jawa yang diangkat dalam penelitian. Sementara nilai-nilai dalam kearifan local siri' na pacce dan tri hita karana merupakan budaya Makasar dan Bali juga banyak digunakan. Selain budaya Toraja, budaya daerah yang juga digunakan dalam artikel dalam kajian adalah budaya Bajo, Maluku, dan suku Maori di Selandia Baru.

Untuk budaya pada tingkat Negara, dari 60 artikel yang ada, budaya Indonesia, Bangladesh, Jepang, dan Thailand secara berurutan yang paling banyak diteliti. Budaya negara lainnya di sini antara lain budaya Turki, Amerika Serikat, Inggris Raya (United Kingdom), Selangor Malaysia, Sri lanka, Zambia, dan Newscatle. Terdapat tujuh artikel menggunakan konsep kearifan lokal yang ada di Indonesia secara umum, seperti budaya tolong-menolong dalam hubungan keluarga dan gotong-royong. Budaya negara tentang feminisme, kebiasaan berdagang, dan penggunaan konsep akuntansi merupakan beberapa konsep kearifan lokal tingkat negara yang digunakan dalam penelitian internasional.

Sementara itu, kearifan lokal untuk jenis atau bentuk berupa religi, etnis, dan ajaran, sebagian besar dipublikasikan dalam jurnal berskala internasional. Religi Islam (empat artikel) dan etnis Cina (tiga artikel) merupakan konsep kearifan lokal yang paling banyak digunakan dalam penelitian di samping religi 
Hindu dan Budha, serta etnis Inggris-Afrika. Penggunaan dimensi budaya menurut ajaran Hofstede yang banyak digunakan dalam penelitian akuntansi merupakan salah satu bentuk kearifan lokal buah pemikiran atau ide seseorang (Hofstede) yang banyak di-amin-i oleh banyak peneliti, termasuk bidang akuntansi.

\section{Metode penelitian}

Berkaitan dengan metode penelitian yang digunakan, dari 60 artikel tersebut, 12 artikel diantaranya secara eksplisit menyatakan menggunakan metode penelitian etnografi dan fenomenologi dalam menggali data. Metode etnografi yang digunakan di sini ada beberapa diantaranya merupakan metode campuran, yaitu entnografi kritis dan etnoarkeologi, serta gabungan antara etnografi dengan grounded theory.

Sebagian besar artikel tidak secara eksplisit menyebutkan metode penelitian yang digunakan dan hanya menyebutkan menggunakan pendekatan kualitatif, paradigma interpretif, pendekatan non-positivism, ataupun dasar teori yang digunakan seperti actor network theory (ANT). Sebagian besar dari artikel ini menggali data melalui wawancara mendalam (dept interview). Jika ditelusuri lebih lanjut, artikel tersebut didominasi oleh artikel nasional ataupun internasional yang menggunakan kearifan lokal budaya daerah (suku) dan budaya negara di Indonesia, dengan kata lain hasil penelitian oleh peneliti Indonesia. Untuk lima artikel dengan metode lainnya, menyebutkan menggunakan grounded theory, arkeologi, spiritualitas, reduksi data, dan sejarah.

Terkait dengan metode penelitian, salah satu hal yang menarik untuk dikaji lebih lanjut adalah cara pengumpulan data. Selain wawancara secara mendalam yang hampir digunakan dalam semua penelitian itu, beberapa penelitian khususnya yang diterbitkan di jurnal internasional bereputasi, juga menerapkan triangulasi data melalui dokumentasi, observasi partisipasi, ataupun observasi lapangan. Penelitian kualitatif tidak mengatur jumlah informan atau responden atau artifak yang harus dipenuhi sebagaimana penelitian kuantitatif. Pemilihan informan kunci yang tepat lebih menjadi perhatian dalam penelitian kualitatif, bukan jumlahnya. Meski demikian, jumlah informan atau responden atau artifak menunjukkan keterwakilan dari populasi yang hendak digambarkan untuk menjawab persoalan penelitian.

Berdasarkan jumlah responden atau artifak yang digunakan, seperti nampak dalam Grafik 1, terdapat 23 artikel (39\%) menggunakan responden berjumlah satu sampai lima orang atau lembaga, yang terdiri dari 10 artikel dengan responden berupa lembaga atau sekelompok unit dan 13 artikel dengan responden individu 


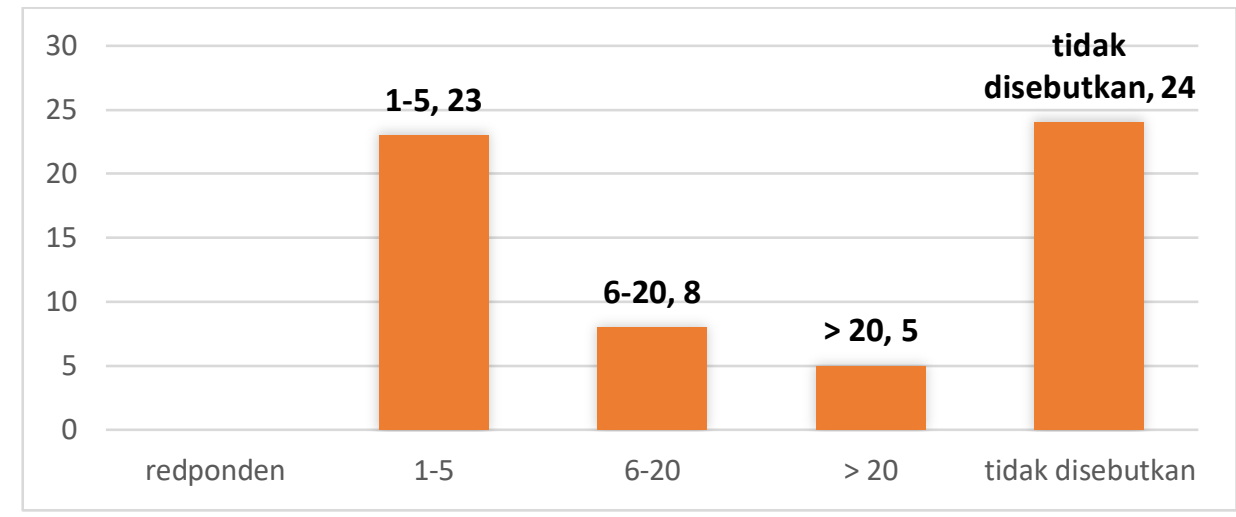

Grafik 1. Penggunaan Jumlah Responden atau Artifak

Demikian halnya artikel yang menggunakan responden berjumlah 6-20, terdiri dari dua artikel dengan responden berupa lembaga atau sekelompok unit, dan sisanya responden individu. Sedangkan, untuk jumlah responden $>20$, hanya satu artikel yang menggunakan artifak sebanyak 35 publikasi (pemikiran Hofstede), sisanya berupa responden individu.

Jumlah responden terbanyak yang digunakan dalam artikel-artikel dalam kajian adalah artikel yang dipublikasikan di Accounting, Organization, and Society yaitu sebanyak 65 responden. Artikel ini meneliti tentang peran karakteristik atau budaya Cina dalam pengembangan regulasi akuntansi. Dalam artikel juga dijelaskan oleh peneliti bahwa membutuhkan waktu 10 tahun untuk melakukan wawancara dengan 65 responden tersebut dalam rangka menggali data. Selanjutnya terdapat dua artikel internasional yang menggunakan responden 25 orang, salah satunya mengangkat konsep kearifan lokal jenis religi yang diterbitkan di Accounting, Auditing, \& Accountability.

Kemudian, terkait dengan 24 artikel yang tidak menjelaskan jumlah responden atau artifak yang digunakan, beberapa di antara artikel tersebut pada dasarnya tidak membutuhkan responden karena artikel merupakan hasil pemikiran atau kritik, sedangkan artikel lainnya memang tidak secara tertulis menyebutkan jumlah responden atau artifak yang digunakan. Ketika dilihat dari metode penelitian, baik metode ataupun jumlah responden yang digunakan, artikelartikel yang dipublikasikan di jurnal internasional berputasi (12 artikel) menerapkan lebih dari semacam metode pengumpulan data dan menggunakan jumlah responden lebih dari 10 orang atau sekelompok unit (lihat Diagram 2). 


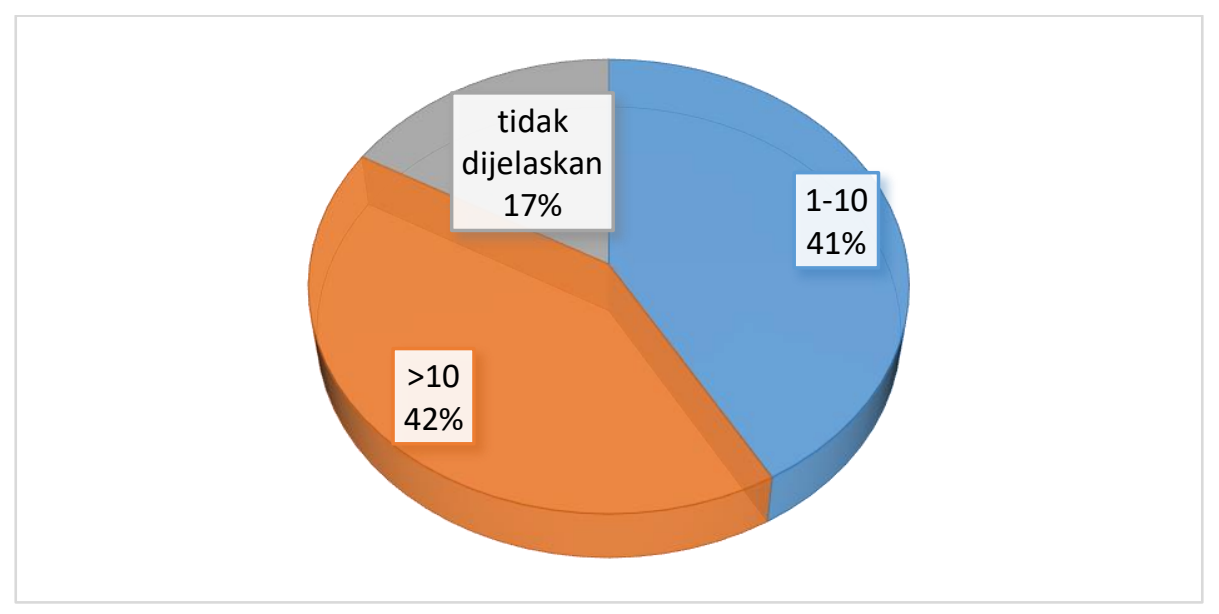

Diagram 2. Penggunaan Jumlah Responden atau Artifak dari 12 Artikel Internasional Bereputasi

Dari dua artikel yang tidak menjelaskan jumlah responden yang digunakan, salah satunya merupakan studi literatur dan satunya menyebutkan menggunakan respoden beberapa pihak berdasarkan fungsi atau profesinya, yaitu local microfinance specialists, manajer, akuntan, klien, loan officer saat ini dan loan officer sebelumnya. Ketika ditelusuri lebih lanjut, artikel dengan responden atau artifak kurang dari 10, menerapkan triangulasi data melalui wawancara, dokumentasi, observasi partisipasi, ataupun observasi lapangan. Perincian tentang kapan, berapa lama, dengan siapa wawancara dilakukan, serta bagaimana dan tujuan observasi juga dijabarkan oleh peneliti. Meskipun penelitian kualitatif tidak banyak menggunakan responden, setidaknya belajar dari artikel internasional bereputasi ini bahwa metode dan penggunaan metode pengumpulan data juga penting untuk dijelaskan secara terperinci.

\section{Tantangan dan Peluang}

Penggunaan konsep kearifan lokal dalam penelitian akuntansi dan bisnis sebagaimana dipetakan dalam tulisan ini, memiliki beragam jenis atau bentuk kearifan lokal, bidang ilmu kajian, maupun metode penelitian. Dari 60 artikel terdapat 12 artikel yang diterbitkan jurnal berskala internasional dan bereputasi. Berdasarkan hasil dan pembahasan di atas dan isi 12 artikel tersebut, dapat ditemukan tantangan yang selanjutnya dapat menjadi peluang untuk meningkatkan mutu penelitian interpretif di Indonesia yang mengangkat konsep kearifan lokal. Setidaknya ada dua pokok pikiran yang bisa dipelajari dari artikel tersebut untuk menjadi tantangan dan peluang bagi peneliti interpretif di Indonesia, yaitu metode penelitian dan jenis atau bentuk kearifan lokal, serta satu tantangan yang lainnya terkait dengan keberanian mental. 


\section{Metode penelitian}

Dari sisi metode penelitian, 12 artikel tersebut menggunakan jumlah responden dan artifak yang bervariasi namun hampir semuanya menggunakan lebih dari satu metode pengumpulan data dan menerapkan triangulasi, ada wawancara, dokumentasi, observasi lapangan, maupun observasi partisipasi. Bahkan, sebagian besar artikel juga menjelaskan secara terperinci proses pengumpulan data (kapan, berapa lama, dengan siapa wawancara dilakukan, serta bagaimana dan tujuan melakukan observasi). Jumlah responden penelitian yang banyak atau sedikit, dengan penggunaan metode penelitian yang tepat dan jelas untuk menjawab problematika yang ada akan menjadikan penelitian tersebut menarik untuk dibaca namun juga diterima kebenarannya.

Sebagai contoh artikel yang berjudul 'Syrian women accountants' attitudes and experiences at work in the context of globalization' oleh Rania Kamla yang diterbitkan di Accounting, Organizations and Society (2012) dan "Exploring accounting presence and absence: case studies from Bangladesh" oleh Kerry Jacobs dan Jeff Kemp yang diterbitkan di Accounting, Auditing, and Accountability Journal (2012). Artikel yang pertama hanya menggunakan metode pengumpulan data wawancara mendalam namun ini dilakukan oleh peneliti dengan 22 responden akuntan wanita Siria yang bekerja di perusahaan profesi akuntansi dan keuangan yang berbeda-beda dan dalam situasi berhijab atau tidak berhijab sebagai ciri budaya wanita Siria. Sedangkan artikel kedua hanya menggunakan tiga orang pedagang kecil di Bangladesh. Namun demikian peneliti dalam mengeksplorasinya menggunakan pendekatan antropologi dengan pengumpulan data melalui wawancara mendalam, dokumentasi, maupun observasi. Dengan metode penelitiannya masing-masing, kedua artikel tersebut dapat menjelaskan temuan dan menjawab problematika penelitian dengan jelas dan dapat diterima kebenarannya, sehingga menarik untuk dipelajari.

Kedua artikel tersebut memberikan tantangan bagi peneliti interpretif di Indonesia, yaitu menggunakan responden banyak meski hanya dengan wawancara cara menggali informasi atau jumlah responden sedikit namun dilengkapi dengan cara eksplorasi data yang berbagai macam. Sementara itu, secara umum peneliti Indonesia ditemukan banyak yang mendasarkan pada satu metode pengumpulan data, yaitu wawancara. Metode penelitian memang bukan inti dari penelitian, tetapi melalui penjelasan metode penelitian dapat diketahui sejauh mana peneliti mampu menjawab persoalan penelitian dengan cara yang memadai sehingga hasil penelitian dapat diterima kebenarannya karena metode penelitian ditujukan untuk menemukan pengetahuan baru, mengembangkan pengetahuan, dan menguji kebenaran suatu pengetahuan (Hadi, 2010). 


\section{Jenis atau bentuk kearifan lokal}

Dari sisi jenis atau bentuk kearifan lokal yang diangkat dalam penelitian, sebagian besar dari 12 artikel itu mengangkat kearifan lokal di tingkat negara dan hanya dua artikel dengan kearifan lokal daerah atau suku, yaitu suku Maori dan Jawa. Kearifan lokal di tingkat negara memiliki cakupan yang lebih luas daripada daerah atau suku sehingga dampak pembahasan kearifan lokal dalam penelitian juga akan lebih luas. Seberapa besar dampak penelitian bagi masyarakat ini menjadi faktor penting yang dipertimbangkan dalam penerimaan dan publikasi jurnal karena ini juga akan mempengaruhi journal impact factor (JIF).

JIF adalah ukuran yang mencerminkan jumlah rata-rata jumlah kutipan tahunan terhadap artikel terbaru yang dipublikasikan di jurnal tersebut dan sering digunakan sebagai proxy untuk kepentingan relatif jurnal di dalam bidangnya (Garfield, 2006). Jurnal dengan faktor dampak yang lebih tinggi sering dianggap lebih penting daripada yang memiliki tingkat dampak yang lebih rendah. Meskipun terjadi perdebatan atas JIF ini namun jumlah sitasi atas jurnal masih banyak digunakan untuk mengukur kualitas jurnal.

Hal ini bukan berarti kearifan budaya daerah atau suku tidak memiliki dampak yang cukup tinggi untuk diteliti. Berdasarkan 12 artikel tersebut, terdapat dua artikel dengan kearifan lokal daerah atau suku, yaitu suku Maori dan Jawa. Budaya Maori dan Jawa adalah kearifan lokal berbasis daerah atau suku namun kita semua tahu bahwa budaya Jawa di Indonesia adalah salah satu budaya yang banyak mempengaruhi aspek kehidupan masyarakat Indonesia yang beragam. Ada kemungkinan karena para presiden di Indonesia, sejak presiden pertama hingga sekarang berasal dari suku Jawa, sehingga budaya daerah Jawa juga kental dalam sistem pemerintahan. Begitu juga dengan budaya suku Maori, mayoritas penduduk Selandia Baru adalah keturunan bangsa-bangsa dari Eropa dengan pribumi Maori adalah minoritas terbesar. Namun, Bahasa Maori menjadi salah satu Bahasa resmi dan sebagian besar budaya Selandia Baru diturunkan dari Maori (NZ History, 2018).Oleh karena itu, dapat dipahami bahwa dampak pembahasan atas budaya suku Maori dalam suatu penelitian akan luas cakupannya sehingga juga akan tinggi JIF-nya.

Selain tingkat budaya kearifan lokal, beberapa artikel dari 12 artikel yang diterbitkan di jurnal internasional bereputasi menjelaskan dan membahas nilai-nilai yang terkandung dalam budaya yang diangkat secara mendalam, yang sering kali juga bersinggungan dengan bentuk kearifan lokal lainnya. Sebagai contoh artikel yang berjudul 'Religious "spirit" and peoples' perceptions of accountability in Hindu and Buddhist religious organizations oleh Kelum Jayasinghe dan Teerooven Soobaroyen yang diterbitkan dalam Accounting, 
Auditing \& Accountability Journal (2009). Dari judul, sekilas dapat diketahui bahwa artikel ini mengangkat tema religi sebagai jenis kearifan lokal. Namun ketika artikel ini dibaca secara utuh, peneliti tidak hanya menggali nilai-nilai yang terkandung dalam agama Hindu dan Budha saja, melainkan juga kaitan nilai-nilai religi tersebut dengan budaya negara Sri lanka dan Mauritius yang menarik untuk dikaji. Melalui artikel ini, pembaca tidak hanya sekedar disuguhkan penjelasan bagaimana orang-orang Hindu dan Budhis dalam mempersepsikan akuntabilitas, tetapi tentang bagaimana orang-orang Hindu dan Budhis di Sri lanka dan Mauritius dalam mempersepsikan akuntabilitas yang ternyata sangat berbeda dengan pandangan orang-orang Barat maupun agama lainnya.

Indonesia memiliki banyak budaya daerah atau suku, maka penelitian ini menggali kearifan lokal terkait budaya daerah atau suku dalam proses peneliian dengan memilih daerah atau suku yang memberikan dampak terhadap kehidupan masyarakat di Indonesia atau dunia yang luas. Contohnya budaya Bali, sebagai destinasi wisata yang sudah bertaraf internasional yang pastinya juga sudah dikenal secara luas, dapat dijajagi untuk mengangkat nilainilai budaya Bali dalam kaitannya dengan bidang akuntansi atau bisnis. Mengangkat budaya Bali dalam penelitian maka dampaknya bisa dirasakan juga secara luas. Budaya Bali terkait erat dengan agama Hindu maka pembahasan budaya ini seharusnya juga menghadirkan pembahasan tentang nilai-nilai agama Hindu. Dengan demikian, ketika artikel tentang budaya Bali dibaca, para pembaca tidak hanya mengenal budaya orang Bali semata, tetapi budaya Bali yang sarat dengan nilai-nilai agama Hindu yang bisa jadi berbeda dengan pandangan agama Hindu di tempat lain.

Berdasarkan uraian di atas, kajian artikel nasional dan internasional hasil penelitian peneliti dari Indonesia, terdapat beberapa artikel yang sudah mengakomodasi metode penelitian atau penggunaan jenis kearifan lokal yang merupakan tantangan dan peluang yang ditemukan dari hasil deskripsi di atas. Oleh karena itu, selain menggunakan keduanya secara memadai dan maksimal dalam penelitian dan penulisannya, maka pengalaman para peneliti lain yang sudah berhasil publikasi di jurnal internasional bereputasi patut dipertimbangkan. Beberapa peneliti menyampaikan bahwa untuk mengirimkan artikel ke jurnal tersebut harus siap dengan waktu yang secara umum lama dan proses yang tidak mudah. Salah satunya adalah tulisan Sujoko Efferin dan Trevor Hopper yang terpublikasi di salah satu jurnal internasional bereputasi, yaitu Accounting, Organizations and Society (lihat lampiran). Menurut penuturan Sujoko Efferin ketika memberikan paparan dalam workshop di suatu perguruan tinggi, mereka harus melakukan revisi hingga sembilan kali agar artikel tersebut diterima secara sah untuk dipublikasikan. 
Lebih lanjut juga disampaikan bahwa kecocokan ide tulisan dengan tema atau tujuan dari jurnal yang dituju serta kesamaan visi dan misi jurnal dengan ide tulisan juga patut dipertimbangkan sebelum mengirimkan tulisan ke jurnal yang dituju.

\section{Simpulan}

Konsep kearifan lokal dalam penelitian di bidang akuntansi dan bisnis, khususnya yang menggunakan paradigma interpretif, telah banyak diteliti dan dipublikasikan di jurnal, baik skala nasional maupun internasional. Namun, hasil penelitian tentang kearifan lokal di Indonesia, baik jenis dan bentuk kearifan lokal budaya daerah/suku ataupun tingkat negara, belum banyak yang terpublikasikan di jurnal internasional bereputasi.

Hasil deskripsi yang didasarkan pada 60 artikel bermuatan kearifan lokal yang dipublikasikan di jurnal nasional maupun internasional, ditemukan bahwa kearifan lokal banyak digunakan dalam bidang kajian ilmu akuntansi manajemen, dengan jenis/bentuk kearifan lokal budaya daerah atau suku, dan banyak menggunakan etnografi sebagai metode penelitian. Belajar dari 12 artikel yang dipublikasikan di jurnal internasional bereputasi dari 60 artikel tersebut, setidaknya terdapat dua hal yang perlu diperhatikan agar hasil penelitian interpretif yang mengangkat kearifan lokal Indonesia layak untuk dipublikasikan di jurnal internasional bereputasi.

Bagi peneliti Indonesia, khususnya peneliti berparadigma interpretif, tantangan dan peluang yang pertama adalah penggunaan metode penelitian yang tepat untuk menjawab problematika dan mampu menjelaskannya secara terperinci dan terstruktur, misalkan pendekatan triangulasi data, wawancara, dokumentasi, observasi lapangan, ataupun partisipasi langsung. Kedua, pemilihan jenis/bentuk kearifan lokal, yaitu memilih kearifan lokal yang memiliki dampak secara luas dan kaitannya dengan jenis/kearifan lokal lainnya.

\section{Daftar Pustaka}

Azjen, I. (1991). The Theory of Planned Behavior. Organizational Behavior and Human Decision Processes., 50(2), 179-211.

Burrel, G., \& Morgan, G. (1979). Sociological Paradigms and Organisational Analysis: Elements of the Sociology of Corporate Life. Arena, Great Britain.

Chariri, A. (2009). Landasan Filsafat dan Metode Penelitian Kualitatif (Paper Workshop Metodologi Penelitian Kuantitatif dan Kualitatif). Semarang.

Chua, W. F. (1986). Radical development of accounting thought. The Accounitng Review, LXI(4), 601-632. 
Craig, R., Taonui, R., \& Wild, S. (2012). The concept of taonga in Ma'ori culture: insights for accounting. Accounting, Auditing \& Accountability Journal, 25(6), 10251047.

Ezzamel, M., \& Xiao, J. Z. (2015). The development of accounting regulations for foreign invested firms in China: The role of Chinese characteristics. Accounting, $\begin{array}{llll}\text { Organizations } \quad \text { and } & \text { 60ciety, } 84 .\end{array}$ https://doi.org/10.1016/j.aos.2015.05.005

Garfield, E. (2006). The History and Meaning of the Journal Impact Factor. JAMA, 259(1), 90-93. https://doi.org/10.1016/s0828-282x(06)70296-3

Hadi, S. (2010). Metodologi Research untuk Penulisan Paper, Skripsi, Thesis dan Disertasi (3rd ed.). Yogyakarta: Penerbit Andi.

Kamayanti, A. (2016). Metodologi Penelitian Kualitatif Akuntansi: Pengantar Religiositas Keilmuan. Malang: Yayasan Rumah Peneleh.

Kamla, R. (2012). Syrian women accountants' attitudes and experiences at work in the context of globalization. Accounting, Organizations and Society, 37(3), 188-205. https://doi.org/10.1016/j.aos.2012.02.002

Komori, N. (2012). Visualizing the negative space: Making feminine accounting practices visible by reference to Japanese women's household accounting practices. Critical Perspectives on Accounting, 23(6), 451-467. https://doi.org/10.1016/j.cpa.2012.04.006

Meliono, I. (2011). Understanding the Nusantara Thought and Local Wisdom. International Journal for Historical Studies, 2(2).

Neuman, W. L. (2014). Social Research Methods: Qualitative and Quantitative Approaches (7th ed.). Boston: Allyn and Bacon.

NZ History. (2018). Te Wiki o Te Reo Māori - Māori Language Week. Retrieved from https://nzhistory.govt.nz/culture/maori-language-week/history-of-themaori-language

Wijayanto, A. (2012). Kearifan lokal dalam praktik bisnis di indonesia. FORUM, 40(2), 6-11.

\section{Lampiran}

Tabel 2. Daftar 60 Artikel Tentang Local Wisdom

\begin{tabular}{clll}
\hline No & \multicolumn{1}{c}{ Judul } & \multicolumn{1}{c}{ Jurnal } & \multicolumn{1}{c}{ Penulis } \\
\hline 1 & $\begin{array}{l}\text { Microfinance: accountability } \\
\text { from the grassroots }\end{array}$ & $\begin{array}{l}\text { Accounting, Auditing \& } \\
\text { Accountability Journal Vol. } \\
\text { 19 No. 3, 2006 pp. 405-427 }\end{array}$ & $\begin{array}{l}\text { Rob Ditchie and Juliana } \\
\text { Siwale }\end{array}$ \\
\hline 2 & $\begin{array}{l}\text { Religious "spirit" and } \\
\text { peoples perceptions of }\end{array}$ & $\begin{array}{l}\text { Accounting, Auditing \& } \\
\text { Accountability Journal Vol. }\end{array}$ & Kelum Jayasinghe \& \\
& $\begin{array}{l}\text { Teerooven } \\
\text { accountability in Hindu and }\end{array}$ & 22 No. 7, 2009 pp. 997- & Soobaroyen \\
& $\begin{array}{l}\text { Buddhist religious } \\
\text { organizations }\end{array}$ & 1028 & \\
\hline
\end{tabular}




\begin{tabular}{|c|c|c|c|}
\hline No & Judul & Jurnal & Penulis \\
\hline 3 & $\begin{array}{l}\text { The concept of taonga in } \\
\text { Maori culture: insights for } \\
\text { accounting }\end{array}$ & $\begin{array}{l}\text { Accounting, Auditing \& } \\
\text { Accountability Journal Vol. } \\
25 \text { No. 6, } 2012 \text { pp. 1025- } \\
1047\end{array}$ & $\begin{array}{l}\text { Russell Craig, Rawiri } \\
\text { Taonui, \& Susan Wild }\end{array}$ \\
\hline 4 & $\begin{array}{l}\text { Exploring accounting } \\
\text { presence and absence: case } \\
\text { studies from Bangladesh }\end{array}$ & $\begin{array}{l}\text { Accounting, auditing, } \\
\text { accountability journal vol } \\
15 \text { no } 2 \text { 2012, pp 143-161 }\end{array}$ & $\begin{array}{l}\text { Kerry Jacobs \& Jeff } \\
\text { Kemp }\end{array}$ \\
\hline 5 & $\begin{array}{l}\text { Management control, culture } \\
\text { and ethnicity in a Chinese } \\
\text { Indonesian company }\end{array}$ & $\begin{array}{l}\text { Accounting, Organizations } \\
\text { and Society } 32 \text { (2007) 223- } \\
262\end{array}$ & $\begin{array}{l}\text { Sujoko Efferin \& } \\
\text { Trevor Hopper }\end{array}$ \\
\hline 6 & $\begin{array}{l}\text { The cosmology of accounting } \\
\text { in mid } 19 \text { th-century Thailand }\end{array}$ & $\begin{array}{l}\text { Accounting, Organizations } \\
\text { and Society } 35 \text { (2010) 596- } \\
627\end{array}$ & $\begin{array}{l}\text { Nooch Kuasirikun \& } \\
\text { Philip Constable }\end{array}$ \\
\hline 7 & $\begin{array}{l}\text { Syrian women accountants' } \\
\text { attitudes and experiences at } \\
\text { work in the context of } \\
\text { globalization }\end{array}$ & $\begin{array}{l}\text { Accounting, Organizations } \\
\text { and Society } 37 \text { (2012) 188- } \\
205\end{array}$ & Rania Kamla \\
\hline 8 & $\begin{array}{l}\text { The development of } \\
\text { accounting eegulations for } \\
\text { foreign invested firms in } \\
\text { China: The role of Chinese } \\
\text { characteristics }\end{array}$ & $\begin{array}{l}\text { Accounting, Organizations } \\
\text { and Society } 44 \text { (2015) 60- } \\
84\end{array}$ & $\begin{array}{l}\text { Mahmoud Ezzamel \& } \\
\text { Jason Zezhong Xiao }\end{array}$ \\
\hline 9 & $\begin{array}{l}\text { Visualizing the negative } \\
\text { space: Making feminine } \\
\text { accounting practices visible } \\
\text { by reference to Japanese } \\
\text { women's household } \\
\text { accounting practices }\end{array}$ & $\begin{array}{l}\text { Critical Perspectives on } \\
\text { Accounting } 23(2012) 451- \\
467\end{array}$ & Naoko Komori \\
\hline 10 & $\begin{array}{l}\begin{array}{l}\text { Accounting colonisation and } \\
\text { austerity in arts } \\
\text { organisations }\end{array} \\
\end{array}$ & $\begin{array}{l}\text { Critical Perspectives on } \\
\text { Accounting } 38 \text { (2016) 34- } \\
53\end{array}$ & $\begin{array}{l}\text { Helen Oakesa \& Steve } \\
\text { Oakes }\end{array}$ \\
\hline 11 & $\begin{array}{l}\text { Participatory budgeting in a } \\
\text { SriLankan urban council: A } \\
\text { Practice of power and } \\
\text { domination }\end{array}$ & $\begin{array}{l}\text { Critical Perspectives on } \\
\text { Accounting } \mathrm{xxx}(2015) \mathrm{xxx}- \\
\mathrm{xx}\end{array}$ & $\begin{array}{l}\text { Chamara Kuruppua, } \\
\text { Pawan Adhikarib, } \\
\text { Vijitha Gunarathnac, } \\
\text { Dayananda } \\
\text { Ambalangodaged, } \\
\text { Priyanga Pereraa, \& } \\
\text { Chaminda } \\
\text { Karunarathnac }\end{array}$ \\
\hline 12 & $\begin{array}{l}\text { Ethics education and the role } \\
\text { of the symbolic market }\end{array}$ & $\begin{array}{l}\text { Journal of Business Ethics, } \\
\text { Vol. 76, No. } 3 \text { (Dec, 2007), } \\
\text { pp. 253-267 }\end{array}$ & Jeff S. Everett \\
\hline 13 & $\begin{array}{l}\text { Lessons from resource } \\
\text { management by indigenous }\end{array}$ & $\begin{array}{l}\text { Ecological Economics } 102 \\
\text { (2014) 1-7 }\end{array}$ & $\begin{array}{l}\text { Viktoria Kahui \& } \\
\text { Amanda C. Richards }\end{array}$ \\
\hline
\end{tabular}




\begin{tabular}{|c|c|c|c|}
\hline No & Judul & Jurnal & Penulis \\
\hline & $\begin{array}{l}\text { Maori in New Zealand: } \\
\text { Governing the ecosystems as } \\
\text { commons }\end{array}$ & & \\
\hline 14 & $\begin{array}{l}\text { Culture and accounting } \\
\text { practices in Turkey }\end{array}$ & $\begin{array}{l}\text { Int. J. Accounting, Auditing } \\
\text { and Performance } \\
\text { Evaluation, Vol. 5, No. 1, } \\
2008\end{array}$ & $\begin{array}{lr}\text { Saeed } & \text { Askary, } \\
\text { Hassan } & \text { Yazdifar, } \\
\text { Davood Askarany }\end{array}$ \\
\hline 15 & $\begin{array}{l}\text { Local wisdom: the } \\
\text { development of community } \\
\text { culture and production } \\
\text { processes in Thailand }\end{array}$ & $\begin{array}{l}\text { International Bibliography } \\
\text { of the Social Sciences (IBSS) }\end{array}$ & $\begin{array}{l}\text { Utit Sungkharat, } \\
\text { Piboon Doungchan, } \\
\text { Chantas Tongchiou, \& } \\
\text { Banlue Tinpang-nga }\end{array}$ \\
\hline 16 & $\begin{array}{l}\text { Accountability of planning on } \\
\text { village fund allocation in } \\
\text { osing community in } \\
\text { Banyuwangi }\end{array}$ & $\begin{array}{l}\text { International Conference } \\
\text { on Accounting Studies } \\
\text { (ICAS) } 2015 \text { 17-20 August } \\
\text { 2015, Johor Bahru, Johor, } \\
\text { Malaysia }\end{array}$ & Taufik Kurrohman \\
\hline 17 & $\begin{array}{l}\text { Understanding the } \\
\text { nusantara thought and local } \\
\text { wisdom as an aspect of the } \\
\text { Indonesian education }\end{array}$ & $\begin{array}{l}\text { International Journal for } \\
\text { Historical Studies, 2(2) } \\
2011\end{array}$ & Irmayanti Meliono \\
\hline 18 & $\begin{array}{lr}\text { Corporate } & \text { social } \\
\text { responsibility model } & \text { based } \\
\text { on "Tri Hita Karana" culture }\end{array}$ & $\begin{array}{l}\text { International Journal of } \\
\text { business and Management } \\
\text { Invention, Volume } 5 \text { Issue } 3 \\
\text { March. } 2016 \text { PP-41-47 }\end{array}$ & $\begin{array}{l}\text { Ni Nyoman Kerti } \\
\text { Yasa, I Putu Gde } \\
\text { Sukaatmadja, I G. A. } \\
\text { Ketut Giantari }\end{array}$ \\
\hline 19 & $\begin{array}{l}\text { Public participation in the } \\
\text { implementation of forestry } \\
\text { decentralization in Indonesia }\end{array}$ & $\begin{array}{l}\text { International Journal of } \\
\text { Administrative Science \& } \\
\text { Organization, May } 2013 \\
\text { Volume 20, Number } 2\end{array}$ & $\begin{array}{ll}\text { Emilianus } & \text { Yakob } \\
\text { Sese Tolo } & \end{array}$ \\
\hline 20 & $\begin{array}{lr}\text { Management } & \text { control } \\
\text { systems } & \text { concept } \\
\text { construction } & \text { of } \\
\text { "pangngadereng" } & \text { based on } \\
\text { local wisdom values }\end{array}$ & $\begin{array}{l}\text { IOSR Journal of Business } \\
\text { and Management (IOSR- } \\
\text { JBM) e-ISSN: 2278-487X. } \\
\text { Volume 8, Issue } 2 \text { (Jan. - Feb. } \\
\text { 2013), PP 21-30 }\end{array}$ & $\begin{array}{l}\text { Abdul Kahar, Iwan } \\
\text { Triyuwono, Gugus } \\
\text { Irianto, \& } \\
\text { Ludigdo }\end{array}$ \\
\hline 21 & $\begin{array}{l}\text { Beyond ceremony: The } \\
\text { impact of local wisdom on } \\
\text { public participation in local } \\
\text { government budgeting }\end{array}$ & JAMAR Vol. 11 • No. 12013 & 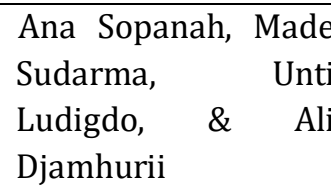 \\
\hline 22 & $\begin{array}{l}\text { Transformation as reversion } \\
\text { to fitrah: Muslim Mãori } \\
\text { women's self-transformation } \\
\text { through reflexive } \\
\text { consumption }\end{array}$ & 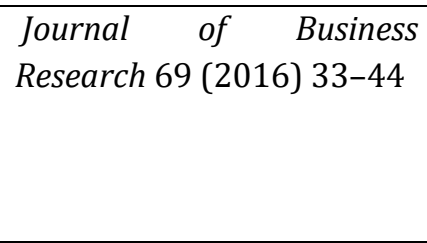 & 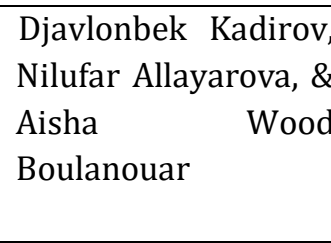 \\
\hline 23 & $\begin{array}{l}\text { The Japanese model of } \\
\text { corporate Management: } A\end{array}$ & $\begin{array}{l}\text { Journal of Japan Society for } \\
\text { Business Ethics Study }\end{array}$ & Akira Saito \\
\hline
\end{tabular}




\begin{tabular}{|c|c|c|c|}
\hline No & Judul & Jurnal & Penulis \\
\hline & $\begin{array}{l}\text { driving force for the } \\
\text { development of Japanese } \\
\text { corporations but also a } \\
\text { Source of ethical difficulties }\end{array}$ & & \\
\hline 24 & $\begin{array}{l}\text { Institutional } \\
\text { entrepreneurship, practice } \\
\text { memory, and } \\
\text { culturalmemory: Choice and } \\
\text { creativity in the pursuit of } \\
\text { endogenous change of local } \\
\text { authority budgeting }\end{array}$ & $\begin{array}{l}\text { Management Accounting } \\
\text { Research xxx (2016) xxx- } \\
\mathrm{xxx}\end{array}$ & $\begin{array}{l}\text { Thomas Ahrensa \& } \\
\text { Laurence Ferry }\end{array}$ \\
\hline 25 & $\begin{array}{l}\text { Hofstede's cultural } \\
\text { dimensions in accounting } \\
\text { research: A review }\end{array}$ & $\begin{array}{l}\text { Meditari Accountancy } \\
\text { Research, 2016, Vol. 24 Iss } \\
\text { 4 pp. - }\end{array}$ & Hichem Khlif \\
\hline 26 & $\begin{array}{l}\text { Biological assets valuation } \\
\text { reconstruction: A critical } \\
\text { study of IAS 41 on } \\
\text { agricultural accounting in } \\
\text { Indonesian farmers }\end{array}$ & $\begin{array}{lll}\text { Procedia - Social } & \text { and } \\
\text { Behavioral Sciences } & 164 \\
\text { (2014 ) 68-75 } & \end{array}$ & $\begin{array}{l}\text { Rendra Kurniawan, } \\
\text { Aji } \\
\text { Mulawarman, \& Ari } \\
\text { Kamayanti }\end{array}$ \\
\hline 27 & $\begin{array}{l}\text { The existence of accounting } \\
\text { on local trade activity in the } \\
\text { Majapahit Kingdom (1293 } \\
\text { AD -1478 AD) }\end{array}$ & 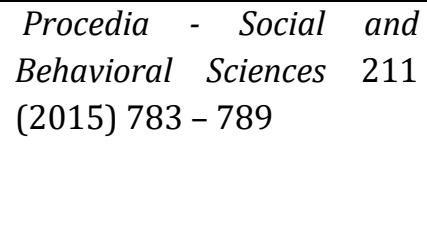 & $\begin{array}{l}\text { Novrida Q. Lutfillah, } \\
\text { Eko G. Sukoharsono, } \\
\text { Aji D. Mulawarman, \& } \\
\text { Yeney } \\
\text { Prihatiningtias }\end{array}$ \\
\hline 28 & $\begin{array}{l}\text { Fair value measurements } \\
\text { (FVMs) rejection and } \\
\text { reconstruction: } \\
\text { phenomenological study of } \\
\text { internal accountantresponse } \\
\text { towards FV accounting and } \\
\text { reporting }\end{array}$ & 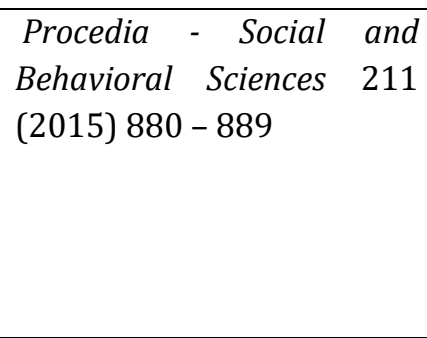 & $\begin{array}{l}\text { Roekhudin, Iwan } \\
\text { Triyuwono, Eko } \\
\text { Ganis Sukoharsono, } \\
\text { \& Rosidi }\end{array}$ \\
\hline 29 & $\begin{array}{l}\text { Local wisdom for sustainable } \\
\text { development of rural } \\
\text { tourism, case on Kalibiruand } \\
\text { Lopati Village, Province of } \\
\text { Daerah r Istimewa } \\
\text { Yogyakartar }\end{array}$ & $\begin{array}{lrl}\text { Procedia } & - \text { Social } & \text { and } \\
\text { Behavioral } & \text { Sciences } & 216 \\
(2016) 97-108 & \end{array}$ & $\begin{array}{l}\text { Vincentia } \\
\text { Vitasurya }\end{array}$ \\
\hline 30 & $\begin{array}{l}\text { Revealing and building the } \\
\text { COSO concept and } \\
\text { Khllifatullah fill ard } \\
\text { philosophy to prevent and } \\
\text { detect the occurrence of } \\
\text { fraud through forensic } \\
\text { accounting }\end{array}$ & 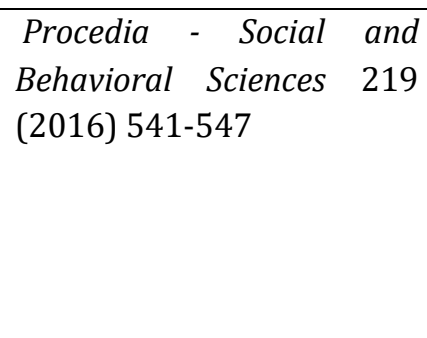 & Hurhayati \\
\hline
\end{tabular}




\begin{tabular}{|c|c|c|c|}
\hline No & Judul & Jurnal & Penulis \\
\hline 31 & $\begin{array}{l}\text { Managing heritage assets: } \\
\text { Issues, challenges and the } \\
\text { future of historic Bukit Jugra, } \\
\text { Selangor }\end{array}$ & 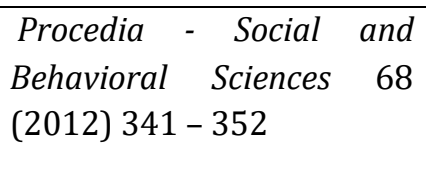 & $\begin{array}{l}\text { Aidatul Fadzlin Bakri, } \\
\text { Nooridayu } \\
\text { Yusuf, \& } \\
\text { Jaini Norajlin }\end{array}$ \\
\hline 32 & $\begin{array}{l}\text { Localism in practice: } \\
\text { investigating } \\
\text { participation and good } \\
\text { governance in local } \\
\text { government standards of } \\
\text { conduct }\end{array}$ & $\begin{array}{l}\text { Public administration } \\
\text { Review, Vol. 74, Iss. 1, pp. } \\
\text { 75-3. }\end{array}$ & $\begin{array}{l}\text { Alan Lawton \& } \\
\text { Michael Macaulay }\end{array}$ \\
\hline 33 & $\begin{array}{l}\text { Review symbolic convergence } \\
\text { of local wisdom in cross- } \\
\text { cultural collaborative social } \\
\text { responsibility: Indonesian } \\
\text { case }\end{array}$ & $\begin{array}{l}\text { Public Relations Review } \mathrm{xxx} \\
\text { (2016) } \mathrm{xxx}-\mathrm{xxx}\end{array}$ & Dorien Kartikawangi \\
\hline 34 & $\begin{array}{l}\text { Religion, spirituality and } \\
\text { entrepreneurship the church } \\
\text { as entrepreneurial space } \\
\text { among British Africans }\end{array}$ & 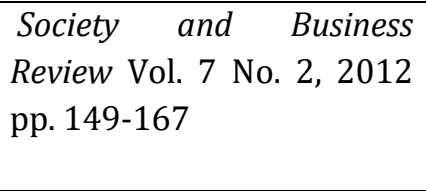 & $\begin{array}{l}\text { Sonny Nwankwo, } \\
\text { Ayantunji Gbadamosi } \\
\text { \& Sanya Ojo }\end{array}$ \\
\hline 35 & $\begin{array}{l}\text { Doing bussiness the Chinese } \\
\text { way? On Manadonese } \\
\text { Chinese entrepreneurship in } \\
\text { North Sulawesi }\end{array}$ & $\begin{array}{l}\text { The Copenhagen Journal of } \\
\text { Asian Studies 24, } 2006\end{array}$ & Michael Jacobsen \\
\hline 36 & \begin{tabular}{ll} 
Traditional & \multicolumn{2}{c}{ sustainability } \\
accounting & principles in \\
Bangladesh & \\
\end{tabular} & $\begin{array}{l}\text { World Journal of Social } \\
\text { Sciences Vol. 5. No. 2. April } \\
\text { 2015 Issue. Pp. } 201 \text { - } 210\end{array}$ & $\begin{array}{l}\text { Mahmood Hasan } \\
\text { Khan, Amzad Hossain } \\
\text { \& Dora Marinova }\end{array}$ \\
\hline 37 & $\begin{array}{l}\text { Household accounting } \\
\text { values and implementation: } \\
\text { An interpretive study }\end{array}$ & 2014 & $\begin{array}{l}\text { Arief Prima Raharjo } \\
\text { \& Ari Kamayanti }\end{array}$ \\
\hline 38 & $\begin{array}{l}\text { Story of bride price: Sebuah } \\
\text { kritik atas fenomena uang } \\
\text { panaik suku Makasar }\end{array}$ & $\begin{array}{l}\text { JAMAL Volume } 6 \text { Nomor } 1 \\
\text { Halaman 1-174 Malang, } \\
\text { April } 2015\end{array}$ & $\begin{array}{l}\text { Syarifuddin \& Ratna } \\
\text { Ayu Damayanti }\end{array}$ \\
\hline 39 & $\begin{array}{l}\text { Paradigma akuntansi } \\
\text { Makasaran dalam hukum } \\
\text { pelayaran dan perdagangan } \\
\text { amanna gappa }\end{array}$ & 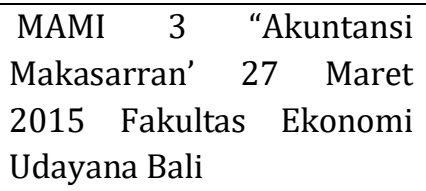 & $\begin{array}{l}\text { Nur Hidayah \& } \\
\text { Rahmat Januar Noor }\end{array}$ \\
\hline 40 & $\begin{array}{l}\text { Memaknai independensi } \\
\text { auditor dengna keindahan } \\
\text { nilai-nilai kearifan local siri' } \\
\text { na pacce }\end{array}$ & $\begin{array}{l}\text { JAMAL Volume } 6 \text { Nomor } 1 \\
\text { Halaman 1-174 Malang, } \\
\text { April 2015 }\end{array}$ & $\begin{array}{l}\text { Nur Alimin } \text { Azis, } \\
\text { Yenni Mangoting, \& } \\
\text { Novrida } \quad \text { Qudsi } \\
\text { Lutfillah }\end{array}$ \\
\hline 41 & $\begin{array}{lr}\text { Tranformasi } & \text { nilai budaya } \\
\text { lokal dalam } & \text { membangun } \\
\text { akuntabilitas } & \text { organisasi } \\
\text { sektor publik } & \end{array}$ & $\begin{array}{l}\text { JAMAL Volume } 5 \text { Nomor } 3 \\
\text { Halaman 345-510 Malang, } \\
\text { Desember } 2014\end{array}$ & $\begin{array}{lr}\text { Fransiskus } & \text { Randa } \\
\text { Fransiskus } & \text { E. } \\
\text { Daromes } & \end{array}$ \\
\hline
\end{tabular}




\begin{tabular}{|c|c|c|c|}
\hline No & Judul & Jurnal & Penulis \\
\hline 42 & $\begin{array}{l}\text { Makna biaya dalam upacara } \\
\text { rambu solo }\end{array}$ & $\begin{array}{l}\text { JAMAL Volume } 6 \text { Nomor } 2 \\
\text { Halaman 175-340 Malang, } \\
\text { Agustus 2015 }\end{array}$ & $\begin{array}{l}\text { Tumirin \& Ahim } \\
\text { Abdurahim }\end{array}$ \\
\hline 43 & $\begin{array}{l}\text { Refleksi perilaku pengguna } \\
\text { laporan keuangan atas } \\
\text { praktik manajemen laba } \\
\text { dalam perspektif weton }\end{array}$ & $\begin{array}{l}\text { JAMAL Volume } 6 \text { Nomor } 3 \\
\text { Halaman 341-511 Malang, } \\
\text { Desember } 2015\end{array}$ & Lilik Purwanti \\
\hline 44 & $\begin{array}{l}\text { Bagaimana masjid dan } \\
\text { masyarakan } \\
\text { memakmurkan? } \\
\text { Pemaknaan akuntabilitas } \\
\text { masjid }\end{array}$ & $\begin{array}{l}\text { JAMAL Volume } 7 \text { Nomor } 1 \\
\text { Halaman 1-155 Malang, } \\
\text { April } 2016\end{array}$ & $\begin{array}{l}\text { Eka Siskawati } \\
\text { Ferdawati \& Firman } \\
\text { Surya }\end{array}$ \\
\hline 45 & $\begin{array}{l}\text { Gusjigang dalam Perspektif } \\
\text { Stakeholder dan Sustainable } \\
\text { pada Industri di Kudus }\end{array}$ & SNA Medan & Dwi Soegiyarto \\
\hline 46 & $\begin{array}{l}\text { Nilai-nilai budaya tri hita } \\
\text { karana dalam penetapan } \\
\text { harga jual }\end{array}$ & $\begin{array}{l}\text { JAMAL Volume } 7 \text { Nomor } 2 \\
\text { Halaman 156-323 Malang, } \\
\text { Agustus } 2016\end{array}$ & $\begin{array}{ll}\text { Tri } & \text { Handayani } \\
\text { Amaliah } & \end{array}$ \\
\hline 47 & $\begin{array}{l}\text { Perilaku komunikasi etnis } \\
\text { tionghoa peranakan dalma } \\
\text { bisnis keluarga (studi } \\
\text { fenomenologi mengenai } \\
\text { perilaku komunikasi etnis } \\
\text { Tionghoa peranakan dalam } \\
\text { bisnis keluarga di Jakarta) }\end{array}$ & $\begin{array}{l}\text { Komunikasi, Vol. IX No. 02, } \\
\text { September 2015: 105-118 }\end{array}$ & $\begin{array}{l}\text { Firda Firdaus Abdi, } \\
\text { Hanny Hafiar, \& Evi } \\
\text { Novianti }\end{array}$ \\
\hline 48 & 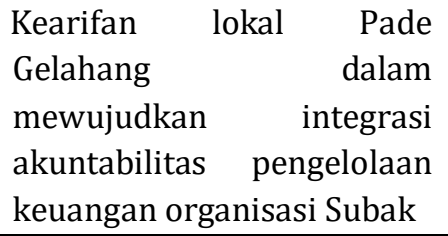 & $\begin{array}{l}\text { JAMAL Volume } 7 \text { Nomor } 1 \\
\text { Halaman 1-155 Malang, } \\
\text { April } 2016\end{array}$ & $\begin{array}{l}\text { Dewa Kadek } \\
\text { Darmada, } \\
\text { Anantawikrama } \\
\text { Tungga Atmadja, \& Ni } \\
\text { Kadek Sinarwati }\end{array}$ \\
\hline 49 & $\begin{array}{l}\text { Fenomena akuntabilitas } \\
\text { perpajakan pada jaman Bali } \\
\text { Kuno: Suatu studi interpretif }\end{array}$ & $\begin{array}{l}\text { JAMAL Volume } 5 \text { Nomor } 3 \\
\text { Halaman 345-510 Malang, } \\
\text { Desember } 2014\end{array}$ & $\begin{array}{l}\text { I Gusti Ayu Nyoman } \\
\text { Budiasih }\end{array}$ \\
\hline 50 & $\begin{array}{l}\text { Menemukan lokalitas } \\
\text { biological assets: pelibatan } \\
\text { etnografis petani apel }\end{array}$ & $\begin{array}{l}\text { JAMAL Volume } 3 \text { Nomor } 3 \\
\text { Halaman 334-501 Malang, } \\
\text { Desember } 2012\end{array}$ & Novan Rizaldy \\
\hline 51 & $\begin{array}{l}\text { Akuntabilitas dalam upacara } \\
\text { adat pemakaman }\end{array}$ & $\begin{array}{l}\text { JAMAL Volume } 6 \text { Nomor } 2 \\
\text { Halaman 175-340 Malang, } \\
\text { Agustus 2015 }\end{array}$ & Selmita Paranoan \\
\hline 52 & $\begin{array}{l}\text { Transformasi } \\
\begin{array}{l}\text { dalam } \\
\text { pedesaan }\end{array}\end{array}$ & $\begin{array}{l}\text { AKP vol } 2 \text { no } 1 \text { Maret } 2004 \\
77-92\end{array}$ & $\begin{array}{l}\text { Tri Pranadji \& } \\
\text { Endang } \quad \text { Lestari } \\
\text { hastuti }\end{array}$ \\
\hline
\end{tabular}




\begin{tabular}{|c|c|c|c|}
\hline No & Judul & Jurnal & Penulis \\
\hline 53 & $\begin{array}{lrr}\text { Kritik } & \text { berbasis } & \text { Teori } \\
\text { Dinamika } & \text { Spiral } & \text { atas } \\
\text { tipologi } & & \text { sistem } \\
\text { pengendalian manajemen }\end{array}$ & $\begin{array}{l}\text { JAMAL Volume } 5 \text { Nomor } 1 \\
\text { Halaman 1-169 Malang, } \\
\text { April } 2014\end{array}$ & $\begin{array}{ll}\text { Abdul Kahar } & \text { \& } \\
\text { Selmita Paranoan } & \end{array}$ \\
\hline 54 & $\begin{array}{l}\text { Akuntansi dalam penetapan } \\
\text { sima masa Jawa Kuno }\end{array}$ & $\begin{array}{l}\text { JAMAL Volume } 5 \text { Nomor } 2 \\
\text { Halaman 170-344 Malang, } \\
\text { Agustus 2014 }\end{array}$ & $\begin{array}{l}\text { Novrida } \\
\text { Lutfillah }\end{array}$ \\
\hline 55 & $\begin{array}{l}\text { Konstruksi tanggung jawab } \\
\text { auditor dalam perspektif } \\
\text { memayu hayuning bawana }\end{array}$ & $\begin{array}{l}\text { JAMAL Volume } 7 \text { Nomor } 1 \\
\text { Halaman 1-155 Malang, } \\
\text { April } 2016\end{array}$ & $\begin{array}{lr}\text { Novrida } & \text { Qudsi } \\
\text { Lutfillah, } & \text { Yenni } \\
\text { Mangoting, } & \text { Riesanti } \\
\text { Edie Wijaya, } & \text { \& } \\
\text { Djurti } \\
\text { Djuharni }\end{array}$ \\
\hline 56 & Kapitalisme lokal suku bajo & $\begin{array}{l}\text { Sodality: Jurnal Sosiologi } \\
\text { Pedesaan, April 2012, hlm. } \\
\text { 36-56 }\end{array}$ & $\begin{array}{l}\text { Nur Isiyana Wianti, } \\
\text { Arya } \\
\text { Dharmawan, Rilus A. } \\
\text { Kinseng, \& Winati } \\
\text { Wigna }\end{array}$ \\
\hline 57 & $\begin{array}{l}\text { Strategi meningkatkan daya } \\
\text { tahan budaya lokal dalam } \\
\text { menghadapi arus globalisasi }\end{array}$ & $\begin{array}{l}\text { Tahun 2011, Volume 24, } \\
\text { Nomer } 4 \text { Hal: 302-308 }\end{array}$ & A. Safril Mubah \\
\hline 58 & $\begin{array}{l}\text { Kearifan lokal dalam praktik } \\
\text { bisnis di Indonesia }\end{array}$ & $\begin{array}{l}\text { FORUM Vol 40, No 2, hal. 6- } \\
11\end{array}$ & Andi Wijayanto \\
\hline 59 & $\begin{array}{l}\text { Akuntansi malangan: Salam } \\
\text { satu jiwa dan konsep kinerja } \\
\text { klub sepak bola }\end{array}$ & $\begin{array}{l}\text { JAMAL Volume } 6 \text { Nomor } 2 \\
\text { Halaman 175-340 Malang, } \\
\text { Agustus 2015 }\end{array}$ & Iwan Triyuwono \\
\hline 60 & $\begin{array}{l}\text { Dissecting of accountability- } \\
\text { based values of Sulapa Appa } \\
\text { wisdom }\end{array}$ & $\begin{array}{l}\text { Asian Journal of Applied } \\
\text { Sciences (ISSN: } 2321 \text { - } \\
\text { 0893) Volume } 05 \text { - Issue 01, } \\
\text { February } 2017\end{array}$ & $\begin{array}{l}\text { Faridah, Gagaring } \\
\text { Pagalung, Alimuddin, } \\
\text { \& Harryanto }\end{array}$ \\
\hline
\end{tabular}

